\title{
Code-switching and transfer: an exploration of similarities and differences
}

Book or Report Section

Accepted Version

refereed chapter in handbook

Treffers-Daller, J. (2009) Code-switching and transfer: an exploration of similarities and differences. In: Bullock, B. E. and Toribio, A. J. (eds.) The Cambridge handbook of linguistic code-switching. Cambridge handbooks in language and linguistics. Cambridge University Press, Cambridge, pp. 5874. ISBN 9780521875912 Available at http://centaur.reading.ac.uk/20711/

It is advisable to refer to the publisher's version if you intend to cite from the work. See Guidance on citing.

Published version at: http://www.cambridge.org/gb/knowledge/isbn/item1174502/?site_locale=en_GB

Publisher: Cambridge University Press

All outputs in CentAUR are protected by Intellectual Property Rights law, including copyright law. Copyright and IPR is retained by the creators or other copyright holders. Terms and conditions for use of this material are defined in the End User Agreement. 


\section{www.reading.ac.uk/centaur}

\section{CentAUR}

Central Archive at the University of Reading

Reading's research outputs online 


\section{Code-switching and transfer: an exploration of similarities and differences}

Handbook article for The Cambridge Handbook of Linguistic Code-switching (pp. 58-74). Editors: Barbara E. Bullock \& Almeida Jacqueline Toribio. Cambridge University Press.

Jeanine Treffers-Daller (University of West England, Bristol)

\section{Introduction}

Over the past thirty years, and in particular since the publication of the groundbreaking work of Pfaff (1979) and Poplack (1980), a wealth of information about code-switching (CS) between a wide range of language pairs has become available. While the popularity of the topic is perhaps unrivalled in the field of language contact, there are important controversies over the nature of the phenomenon and how to delimit it from other contact phenomena, in particular borrowing. Sometimes the problem is that researchers use different terminology for phenomena that are in essence the same, but in other cases researchers appear to be investigating different phenomena altogether, which means that drawing conclusions from a range of studies is difficult (see Jarvis 2000 for similar comments regarding research about transfer). As Meuter (2005: 350) puts it, the focus of most psycholinguistic studies is on "the controlled and willed selection of single responses in a bilingual setting and not on language switching as it occurs spontaneously and (un)intentionally in code switching". Psycholinguists often use the term LANGUAGE SWITCHING for the controlled and willed switching to another language, while this term is hardly ever used by linguists working on naturalistic CS (see Gullberg et al., this volume).

The confusion around terminology and definitions is compounded when one tries to incorporate findings from neighboring disciplines, such as Second Language Acquisition (SLA) or Psycholinguistics, into research on CS, because each discipline favors its own terminology. 
Linguists use a wide variety of terms to indicate different bilingual behaviors, including CS (see section 2). There is also an abundance of terms used to refer to the influence of one language on another. Since the demise of contrastive analysis (Lado 1957), researchers in SLA avoid the term INTERFERENCE and use TRANSFER or CROSSLINGUISTIC INFLUENCE instead, while psycholinguists continue to use the term interference, and researchers in contact-induced language change talk about CONVERGENCE, INTERSYSTEMIC INFLUENCE OR SUBSTRATE/SUPERSTRATE/ADSTRATE INFLUENCE.

The focus of this chapter is to present a review of the definitions employed in the extant literature on bilingualism and language contact. Although many researchers think of CS and interference or transfer as different phenomena, instances of CS and transfer can be seen as similar in that they involve the occurrence of elements of language $A$ in stretches of speech of language B. The term "elements" is used for want of something better, as there is no other term to cover the wide variety of phonological, morphological, syntactic, semantic and conceptual features, lexical items, phrases, clauses, multiword chunks and graphemic symbols that can be transferred from one language to another.

One of the important developments in the past few years is that scholars are increasingly seeking to show how CS research can be made relevant for different fields, such as psycholinguistic models of speech processing or theories of language change. Thus, CS is studied not only as a subject in its own right, however justified the aim of formulating (universal) constraints on this phenomenon or proving its significance in a particular socio-linguistic context may be. Instead, it is becoming increasingly evident that CS research needs to inform and be informed by models of speech processing, theories of language variation and change and SLA and that studying CS in isolation from other disciplines may not be fruitful (see also Boeschoten 1998). Using a unified 
conceptual framework will also considerably enhance the potential impact of insights from CS studies on other fields.

For the purposes of this chapter, the evidence accumulated by researchers in SLA on L1 transfer (Kellerman and Sharwood Smith 1986; Gass 1996; Jarvis 2000;

Pienemann 1999) is particularly relevant. As will be shown, a fuller understanding of the similarities and differences between CS and transfer can no doubt be obtained if we cross the boundaries of various disciplines, and integrate the findings from SLA into our models.

\section{Pertinent distinctions across the disciplines}

Poplack (1990) and De Bot (1992) point to the difficulty of distinguishing different contact phenomena from each other. According to De Bot (1992: 19) "Many instances of cross-linguistic influences [sic] are related to code-switching and cannot be simply separated from this on theoretical or empirical grounds." For Poplack (1990: 39) "each of the mechanisms for combining material from two grammars within a single utterance results from different processes and is governed by different constraints," and Grosjean (1995: 263) expresses a similar point of view, but Paradis (1998; in De Bot 2002: 291) argues that in terms of processing, cross-linguistic influence cannot be distinguished clearly from CS phenomena.

Poulisse and Bongaerts (1994) draw parallels between CS and speech errors, and argue that accidental switches to the $L 1$ are very similar to substitutions and slips in monolingual speech, but Winford (2003: 109) sees clear linguistic and sociolinguistic differences between CS and interference. Whether or not CS and transfer correspond to the same or different psycholinguistic processes, and whether or not contact phenomena 
are intrinsically different from substitutions and slips in monolingual speech is a key issue for research in bilingualism, but it is far from being settled, as the different positions of researchers indicate.

Considering CS and transfer as similar phenomena is helpful if one wants to create a theory that is as parsimonious as possible, and therefore it is worth attempting to aim for such a unified approach, unless there is compelling evidence that this is not possible. A key issue that needs further investigation in this context is how speakers can control CS and transfer. While it is clear that speakers can decide when to switch and when not to, it is less obvious that they can control transfer in the same ways. As Grosjean (2001: 7) puts it, speakers may produce interference "even in the most monolingual of situations." This inability of speakers to control (certain forms of) transfer may be an indication that there are at least some differences in the psycholinguistic processes behind CS and transfer. The issue of control also seems important to distinguish SMOOTH from FLAGGED CODE-SWITCHING (Poplack 1987). Smooth CS is effortless and fluent, whereas flagged switching draws attention to itself, marked by repetitions, hesitations, metalinguistic comments and the like.

De Bot (2002) uses the term MOTIVATED SWITCHING for those instances of CS where speakers switch deliberately to the other language, whereas unintentional CS is labelled PERFORMANCE SWITCHING. While this terminology is not frequently used, the difference between the flagged CS patterns of French-English bilinguals in Ottawa-Hull and smooth CS practiced by Puerto-Rican-English bilinguals in New York City described by Poplack (1987) can illustrate these two types of code-switching.

Researchers working on code-switching from a discourse analytical perspective (Scotton \& Ury 1977; Myers-Scotton 1993b; Auer 1984, 1998; Li Wei 1998; Heller 1988; Moyer 1998) have shown that CS can indeed be intentional and that individual reasons for choosing particular items can be spelled out in detail. However, most researchers 
would probably agree that it would be hard to come up with reasons for every individual switch in examples such as (1) in which there is a continuous back and forth switching between Spanish and English.

(1) OYE (listen), when I was a freshman I had a term paper to do... And all of a sudden, I started acting real CURIOSA (strange), you know. I started going like this. Y LUEGO DECIA (and then I said), look at the smoke coming out of my fingers, like that. And then ME DIJO (he said to me), stop acting silly. Y LUEGO DECIA YO, MIRA (and then I said, look) can't you see. Y LUEGO ESTE (and then this), I started seeing like little stars all over the place. Y VOLTEABA YO ASINA Y LE DECIA (and I turned around and said to him) look at the... the... NO SE ERA COMO BRILLOSITO ASI (I don't know it was like shiny like this) like stars (Valdés Fallis 1976: 70)

Transfer of linguistic features can also happen spontaneously and unintentionally, but this is clearly not the case whenever transfer is used as a strategy (see below) or when the elements that have been transferred have permanently entered the borrowing language.

The distinction made by Paradis (1993) and Grosjean (2001) between DYNAMIC and STATIC INTERFERENCE is very useful in this context. Paradis sees dynamic interferences as performance errors in speech production, when an element of one language appears inadvertently in a sequence of another language. For Grosjean (2001:7) dynamic interferences are "ephemeral deviations due to the influence of the [ ] deactivated language." Static interferences are those that have become part of the implicit grammar of an individual. An example of the latter is the use of une fois "lit. once (mostly untranslated)" in Brussels French, which can be traced back to influence of Dutch in some uses, and has become established in Brussels Dutch (Treffers-Daller 2005b). 
One might equally want to explore to what extent CS can be seen as dynamic or static. While most researchers emphasise the creativity involved in CS behaviour, and thus appear to see CS as a dynamic process in which grammars interact in speech production, not all forms of CS are necessarily entirely creative or dynamic. An example could be the use of the slogan Let's make things better, as used in Dutch advertisements by Philips. Other examples are switches of chunks (Backus 2003) or multiword units (Treffers-Daller 2005a) which illustrate the occurrence of fixed patterns in CS. Finally, could be found in situations where CS has become more or less institutionalized, for example when a mixed code has become the norm of an elite, as Swigart (1992) shows to be the case for Wolof-French CS in Dakar. A new perspective on the controversy around the distinction between borrowing and CS may also be possible if the former was redefined as static CS. Thus CS, transfer and borrowing may have more in common than had been previously thought (see also section 3), especially if these phenomena are considered from a psycholinguistic perspective.

The distinction between static and dynamic interference appears not to have been picked up by researchers working on transfer in either SLA or language contact studies (but see Treffers-Daller 2005), possibly because the term interference is suspect for many researchers outside the field of psycholinguistics. As evidence from speech processing becomes more and more important in a range of disciplines, it may well be timely to exploit the distinction more in theories of CS and transfer. One of the questions that would need to be answered in research in the future is of course to what extent dynamic and static forms of CS are processed differently.

\section{Psycholinguistic approaches to language selection, switching and interference}

Normally functioning bilingual speakers are able to separate their languages in speech production: they can produce monolingual utterances whenever the situation or the 
interlocutor require it. This rather obvious fact is a problem for models of speech processing, which need to account for bilinguals' ability to control their output so that they do not code-switch continuously or experience continued interference (Costa, La Heij and Navarrete 2006). Like bilinguals, monolinguals also need to exercise control in choosing the right words from a number of competing alternatives. In contrast to monolinguals, bilinguals have translation equivalents for at least a proportion of their vocabularies. As a consequence, accounting for the "hard problem" (Finkbeiner, Gollan and Caramazza 2006: 153) of how to avoid inappropriate choices is particularly difficult in models of bilingual speech production. Recent psycholinguistic research is focused on identifying the locus and manner in which bilinguals control their language choices. Kroll, Bobb and Wodniecka (2006: 124) opt for a language-nonselective model of speech production because there is "a great deal of evidence that suggests that candidates in the unintended language are active, that they compete with one another for selection." La Heij (2005), on the contrary, assumes a language-selective model, in which only those lexical items are activated that are selected that correspond to the information contained in the pre-verbal message. La Heij assumes that in bilingual speakers, the intention to speak is part of the preverbal message, so that translation equivalents from the non-response language become less activated than words from the intended language. While the debate is far from being settled, it is clear that all models of bilingual speech production need to account for different kinds of interference from the non-response language (speech errors, blends, etc.), and all models also need to be able to account for different kinds of CS as will be illustrated below.

Before reviewing the implications of these models and findings for CS research, it is important to note a number of relevant facts of bilingual processing. First of all, there is a consensus in psycholinguistics that bilinguals can perhaps "turn down" one of their languages, but that they cannot completely "turn off" that language (Grosjean 2001). Second, bilingual word recognition is basically language non-selective (Dijkstra 2005), that 
is, words from both languages are activated in the process of understanding the incoming speech signal. Third, languages are probably not stored separately, but according to the "subset hypothesis" (Paradis 1981, 2004; De Bot 1992), they form subsets within a larger unit in the brain. Fourth, evidence from neuro-imaging suggests that no major differences in brain activity are found in processing of stories in L1 and $L 2$ among highly proficient bilinguals, but that different patterns of cortical activity are found for less proficient bilinguals performing the same task (Abutelabi, Cappa \& Perani 2005). Thus, one cannot easily locate the two languages of a bilingual in separate areas of the brain (see Kutas et al., this volume), at least not in highly proficient bilinguals, although each language is "susceptible to selective pathological inhibition" (Paradis 2004: 111), a fact that is compatible with the subset hypothesis.

Most authors adopt Levelt's (1989) speech production model (see Wei, this volume), but assume it needs adaptation to account for bilingual speech production. The best known adapted models are Grosjean's (1988) Bilingual Model of Lexical Access, Green's (1998) Inhibitory Control model and Dijkstra and Van Heuven's (1998; 2002) Bilingual Interactive Activation model (BIA). De Bot (1992; 2002), Green (1998) and La Heij (2005) propose, with most other authors in the field, that the decision to speak one language or the other must be taken at the level of the preverbal message, i.e. this is the task of the conceptualizer in Levelt's model. Poulisse and Bongaerts (1994) and Green (1998) propose that lemmas, which contain the lexical entry's meaning and syntax, are tagged with a language label ${ }^{1}$. In Green's Inhibitory Control model, it is the activation of this tag together with the conceptual information that leads to the selection of a given lemma, with any highly active competing lemma inhibited. According to Paradis (2004) however, there is no need for a language tag, and language processing in monolinguals

\footnotetext{
${ }^{1}$ Long ago, Haugen (1972a: 314) also assumed the existence of language tags to ensure speakers are able to keep their languages apart.
} 
and bilinguals is very similar. He assumes that it is lexical meaning which drives the selection of the appropriate lexical item. As the meaning of a word is language-specific, and the meanings of translation equivalents overlap only partly, the formulator should be able to select the right lemma on the basis of its semantic information, by selecting the lemma that maps best onto the information in the preverbal message.

According to Paradis (2004: 212), the implicit grammar of code-mixing (see section 3 for this notion) does not require anything beyond the requirements the individual languages: "the only constraint seems to be that each speech segment of a mixed utterance should not violate the grammar of the language of that segment", a proposal that MacSwan formulated earlier in syntactic-theoretical terms (see MacSwan 1997 and this volume). Paradis recognises that not every single switch can be the result of a decision at the initial planning stage (i.e., at the stage of the pre-verbal message). It would be counter-intuitive, given the frequency of switching within a stretch of speech such as (1), that speakers plan in detail at which points to switch at this early stage, when the focus is on conceptual organization rather than form. He assumes that deliberate CS occurs by virtue of the same principles which make "inadvertent" CS possible.

Most researchers agree that the decision to choose one language as the basic language of the conversation enhances the likelihood that lemmas from that language are being activated. Paradis' (1987; 2004) Activation Threshold Hypothesis accounts for this in such a way that the activation levels of the selected language are raised so as to avoid interference. When speakers are in a bilingual mode (Grosjean 1995), the activation thresholds for both languages are lowered, to allow for CS. As we will see below, the Activation Threshold Hypothesis is however not sufficient to account for the different types of naturalistic CS that Muysken (2000) distinguishes, and it makes a number of predictions that are not borne out by the facts. 
Paradis' hypothesis that lexical selection in monolinguals is similar to lexical selection in bilinguals is attractive in that it is a parsimonious theory, in fact a null hypothesis, and researchers from different fields can look for evidence in support of or against this hypothesis. It is not difficult to see that the tools provided in Paradis' model are necessary but not sufficient to account for naturalistic code-switching.

According to Paradis' (2004: 224) Activation Threshold Hypothesis "in the case of extremely frequently used items, such as closed-class grammatical morphemes, the threshold may be so low as to show no fluctuation because of the strong frequency effect." This is problematic for theories of code-switching, because it predicts that, in the absence of additional constraints on code-switching, interference in the use of closed class items should be frequent. It also predicts that code-switching of adpositions (pre- and postpositions), which are frequent in most languages that possess this category should be common. These two predictions are not borne out by the data. The reason for the lack of code-switching in these categories is probably the lack of CATEGORIAL EQUIVALENCE (Muysken 1995; 2000) or CONGRUENCE (Sridhar and Sridhar 1980; Sebba 1998, MyersScotton 2002; Deuchar 2005) between adpositions from different languages or between functional categories across languages. As is well-known the spatial systems covered by adpositions differs from language to language (Jarvis and Odlin 2000), and determiner systems differ widely from language to language as well, which may inhibit code-switching (cf. the discussion about Arabic versus Dutch determiners in Nortier 1990). Paradis does not clarify the role of congruence in his framework, but it is clear that it needs to get a role, for example as a metalinguistic tool which can be used by speakers to identify where languages have parallel categories or structures. This issue is important for theories of transfer in SLA as well, because the extent to which speakers perceive their L1 and their L2 to be similar or different has an impact on their use of transfer as a strategy for language learning (Odlin 2003). The discussion around perceptions of interlingual identification in 
SLA is unfortunately currently completely separate from discussions around congruence in code-switching but researchers would benefit from knowledge exchange in this area too.

Paradis' model cannot explain either why there are systematic differences in codeswitching patterns (alternation, insertion and congruent lexicalization), as distinguished by Muysken (2000), nor how this typology interacts with issues of control, language typological factors and societal factors. While Paradis' model is able to account for interindividual differences in lexical choice and or switch habits in terms of differences in activation of rules or words from both languages, it cannot explain the systematic differences in types of codeswitching which go beyond the idiosyncratic choices of an individual and which linguists explain on the basis of principles of linguistic theory in interaction with societal factors.

Some models of processing of bilingual speech are based on the idea that languages are either "on" or "off". However, this is not plausible given the psycholinguistic evidence sketched above (cf Muysken 2000). Rather, we probably need to assume with Sridhar and Sridhar (1980: 413) that both systems are on [original emphasis] at the same time, although we now know that they can be on to different degrees. Furthermore, while some researchers define CS as a "complete switch" from one language to the other (Poplack and Meechan, 1995; Grosjean 2001), it is not clear what switching "completely" to the other language means given the psycholinguistic evidence about continued activation of both languages in production and perception.

\section{Definitions and types of code-switching}

Uriel Weinreich (1953:1), a pioneer of contact linguistics, uses the notion "interference" as the over-arching concept for a range of language contact phenomena: "those instances of deviation from the norms of either language, which occur in the speech of bilinguals as a result of their familiarity with more than one language, i.e. as a result of language contact." In Weinreich's definition, interference can be observed at different 
levels of analysis, including the lexical level. Under this view, borrowing and CS can be seen as instantiations of interference, although he does not explicitly formulate it in this way. As is well known, Weinreich (1953: 73) adopts a negative attitude towards CS:

"[T]he ideal bilingual switches from one language to the other according to appropriate changes in the speech situation (interlocutors, topics, etc.), but not in an unchanged situation, and certainly not within a sentence."

Some researchers continue to use one umbrella term for CS, borrowing and transfer. Clyne (2003: 72), for example, uses the notion TRANSFERENCE to cover the phenomena which Weinreich describes as "interference", as the term CS has become so polysemous and unclear. For Clyne, transference can take place at a range of levels of analysis, and certain types of CS (in particular insertional code-mixing - see below) are seen as instantiations of transference, whereas he considers other types of CS (alternation and congruent lexicalization) as examples of TRANSVERSION (see below). Furthermore, he distinguishes between the process (transference) and the product (transfer) of language contact.

Other authors see transfer and CS as different phenomena that cannot be subsumed under a single term. Poplack and Meechan (1995: 200) emphasize the fact that in CS the languages are clearly separate from each other, and they define CS as "the juxtaposition of sentences or sentence fragments from two languages, each of which is internally consistent with the morphological and syntactic (and optionally, phonological) rules of its lexifier language." This definition is reminiscent of McClure's (1977) use of the terminology. McClure (1977: 97) uses the term code-switching to cover code-changing and code-mixing. In McClure's definition, CODE-CHANGING is the alternation of languages at the level of the major constituents (e.g. NP, VP, S). Importantly, she sees codechanging as involving a complete shift [emphasis added] to another language system, in that all function words, morphology and syntax are abruptly changed, whereas code- 
mixing takes place within constituents. Grosjean (1995: 263) defines CS along similar lines as shifting completely [emphasis added] to the other language for a word, a phrase, a sentence, etc. Finally, Clyne (2003: 76) uses the term TRANSVERSION "to express 'crossing over' to the other language rather than alternating between the languages (original emphasis)". The emphasis on separation probably results from the need felt by many researchers in the 1990s to distinguish between borrowing and CS. Borrowing is seen by many researchers as the integration of features from one language into another (see also Thomason and Kaufman's definition of borrowing below). In Thomason and Kaufman's (1988) definition of borrowing (see below) the source language and the recipient language play very different roles, but in some CS models the contact languages are equally assumed to be unequal partners, so that CS and borrowing are not necessarily different on this point.

For Myers-Scotton (1993a) CS does not necessarily involve a complete switch to the other language. In her Matrix Language Frame Model (henceforth MLF model), one of the two languages generally takes a more predominant role in CS in that it determines the grammatical frame of the utterance. This language is considered to be the matrix language (or 'base' language) of the interaction, and the other is the embedded or 'guest' language. In what Myers-Scotton (2006: 241) calls CLASSIC CODE-SWITCHING, elements from two or more language varieties are found in the same clause, but only one of these varieties is the source of the morpho-syntactic frame for the clause." Arguably then, in classic CS, there is no complete switch to the other language, because the syntactic frame of the entire utterance comes from one language. The interaction between the grammars of both languages is more pronounced in another type of CS, which is called COMPOSITE CODE-SWITCHING, in which the guest language contributes some of the abstract structure underlying surface forms in the clause (Myers Scotton 2006: 242). 
Muysken (2000: 1) uses the term code-mixing instead of intra-sentential CS to refer to "all cases where lexical items and grammatical features from two languages appear in one sentence." Muysken's typology of code-mixing (insertion, alternation and congruent lexicalization) is very helpful in that it shows that on the one hand, there is CS in which the languages are clearly kept separate (alternation), as in (2), where the main clause is in French and the subordinate clause is in Dutch, but the two are separated by an interjection.

(2)

$\begin{array}{lllll}\text { Je téléphone à } & \text { Chantal he, meestal voor commieskes } \\ \text { I call } & \text { to } & \text { Chantal } & \text { INT, mostly } & \text { for shopping }\end{array}$

te doen en eten

to do and food

"I call Chantal to go shopping and get food." (Treffers-Daller 1994: 213)

Finally, there are forms of CS in which the contact languages are not kept separate at all (congruent lexicalization). When the two languages in contact are closely related through either the lexicon or the grammar or both, or perceived by speakers to be related, it is often not possible to attribute the syntactic structure of the language to one or the other of the two languages. Thus, while Haugen (1972b: 80) felt that "except in abnormal cases speakers have not been observed to draw freely from two languages at once", in congruent lexicalization, there is a syntactic frame which is shared by both languages, and this is filled with lexical items that can come from both languages, too. This kind of CS is often found in those contact situations where convergence of the contact languages is taking place, and it is somewhat similar to style-shifting in 
monolingual discourse (see Hymes 1972). The following example is from Sranan-Dutch CS. In (3) there is frequent back-and-forth switching between Dutch and Sranan.

$\begin{array}{llll}\text { wan heri gedeelte de ondro beheer fu } & \\ \text { one whole part } & \text { COP under control of }\end{array}$

gewapende machten

armed forces

"One whole part is under control of the armed forces." (Bolle 1994: 75; in Muysken 2000: 139)

And finally, in Muysken's third type of code-mixing, insertional code-mixing (which corresponds to Myers-Scotton's classic CS) lexical items or entire constituents from one language are inserted into a structure from the other language, as in (4), where the Spanish phrase las dos de la noche 'two at night' is surrounded by matrix language elements (from Quechua) in which the Spanish words are nested (A-B-A structure), and noche is integrated into Quechua with the help of the accusative suffix -ta.

(4) Chay-ta las dos de la noche-ta chaya-mu-yku

That-AC the two of the night-AC arrive-CIS-1pl

"There at two in the morning we arrive." (Muysken 2000: 63)

If we were to rank the three types of codemixing distinguished by Muysken on a scale of separation of the languages, then alternation would be a type of code-mixing with maximum separation, and congruent lexicalization would be at the opposite end (minimum separation), with insertional code-mixing occupying the middle ground. 
minimum

Alternation

insertion

congruent lexicalization

We do need to keep in mind, though, that researchers' understanding of separation between languages may not correspond to speakers' perceptions, as Auer (1984: 26) points out. Auer $(1984 ; 1995)$ uses a terminology that differs from that used by others by adopting the overarching concept of LANGUAGE ALTERNATION which covers CODESWITCHING and TRANSFER. Code-switching is defined by Auer as "language alternation at a certain point in conversation without a structurally determined (and therefore predictable) return into the first language", whereas "transfer is defined as language alternation for a certain unit with a structurally provided point of return into the first language" (Auer 1984: 26) ${ }^{2}$. These distinctions correspond- roughly — to Muysken's alternational code-mixing and insertional code-mixing. As the term transfer is used in a very different way in research on language contact and second language acquisition (see below), Auer's terminology has not been widely adopted.

It is also possible to hypothesize that these three types of code-mixing differ from each other with respect to speakers' ability to control their switching. Alternational codemixing seems to be on the side of maximum control, whereas congruent lexicalization is on the opposite side of the continuum, with insertion occupying the middle ground. Of course this hypothesis needs to be corroborated with experimental evidence.

Control continuum

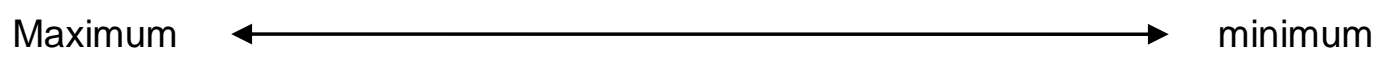

\footnotetext{
2 Auer (1984: 103) points out that the terms Umschaltung (switching) and Einschaltung (transfer) coined by Stolt (1964) are at the basis of his use of the terminology.
} 
Alternation

insertion

congruent lexicalization

Separation between contact languages, and the fact that languages can become more or less similar to each other through contact is key in any discussions of convergence and transfer, to be discussed next.

\section{Convergence and transfer in language change and in Second Language}

\section{Acquisition}

As the terms convergence and transfer are often used alongside each other by many researchers working on contact-induced language change, these concepts are discussed together in this section, with an attempt to clarify how researchers see the relationship between CS on the one hand and transfer/convergence on the other. The discussion first addresses the work of researchers who focus on the role of transfer/convergence in language contact and language change, and then on the work of researchers in SLA, who prefer to use the term "transfer" or "crosslinguistic influence" (Kellerman and Sharwood Smith 1986). Researchers working on transfer or convergence from the perspective of theories of language change have most often focused on the outcome of language contact, or what Paradis (1993) and Grosjean (2001) have termed STATIC INTERFERENCE, referring to features that have become part of the implicit grammar (see section 1). Researchers working on SLA tend to focus on DYNAMIC INTERFERENCE. The discussion below will reflect those tendencies in the literature.

\subsection{Convergence and transfer in contact-induced variation and change} According to Salmons (1990: 476) the notion of convergence goes back to Johannes Schmidt's (1872) Wellentheorie (wave theory), and it is also used by Trubetzkoy (1939) and later by Weinreich (1959: 395) who defines convergence as 'partial similarities 
increasing at the expense of differences'. Hock (1991: 492) adds an important dimension by proposing that "convergence between different languages may be mutual (between adstratal languages) or unidirectional (in an unequal prestige relationship)", and the same point is made by Bullock and Toribio (2004: 91 ).

Pfaff (1979: 315) is probably the first to raise the issue of the relationship between CS and convergence. According to Pfaff CS may lead to convergence, whereas Clyne (1987: 753) appears to imply that convergence may lead to CS, when stating that "syntactic convergence will take place around the switch, apparently in order to ease code switching" [original emphasis]. Clyne (2003: 79) uses the term convergence in general to denote "making languages more similar to each other", and specifically distinguishes between syntactic transference and convergence. Syntactic transference leads to a morpheme-to-morpheme correspondence between the contact languages (as in 4a). Syntactic convergence results in an approximation of the two languages, but not in completely parallel structures, as in (4b), where there is convergence to English in the choice of the auxiliary (haben 'to have' instead of sein 'to be'), in the extraposition of in Tarrington to the right-hand side of the verb, and in the omission of case marking on the preposition zu 'to'.

(4a) Wir haben gegangen zu Schule in Tarrington (syntactic transference)

We have gone to school in Tarrington.

(4b) Wir haben zu Schule gegangen in Tarrington (syntactic convergence)

We have to school gone in Tarrington

(4c) Wir sind in Tarrington zur Schule gegangen (Standard German version)

We are in Tarrington to school gone

"We went to school in Tarrington." (Clyne 2003: 79/80)

While Thomason and Kaufman (1988) do not discuss CS in any detail, their framework for contact-induced language change is one of the most influential works on 
transfer, which they term interference. They distinguish two basic mechanisms of contact-induced change: BORROWING and INTERFERENCE THROUGH SHIFT. Borrowing is defined as "the incorporation of foreign features into a group's native language by speakers of that language: the native language is maintained but is changed by the addition of the incorporated features" (Thomason \& Kaufman 1988: 37). Interference through shift is "a type of interference that results from imperfect group learning during a process of language shift. That is, in this kind of interference, a group of speakers shifting to a target language fails to learn the target language perfectly (Thomason \& Kaufman 1988: 39). In an application of these mechanisms to Brussels, Treffers-Daller (1999) showed that the contact phenomena found in Brussels French are the result of interference through shift, because large groups of speakers of Brussels Dutch learned French, and often abandoned Dutch in the process, whereas the contact phenomena found in Brussels Dutch are the result of a process of borrowing from French. The concepts of borrowing and interference through shift roughly correspond to Van Coetsem's (1988) notions RECIPIENT LANGUAGE AGENTIVITY (e.g. when speakers of Brussels Dutch borrow features from French) and SOURCE LANGUAGE AGENTIVITY (e.g. when Dutch learners of French import features of Dutch into their interlanguages).

Bullock and Toribio (2004: 91), like Silva-Corvalán (1986; 1994), argue that convergence is not necessarily externally induced, and in their point of view this distinguishes convergence from interference or transfer, as the latter concepts refer to externally motivated innovations. They also make an important point regarding the areas of the grammatical system that are particularly prone to external influence and point out that "the convergence of grammatical properties is either of a lexical nature or it occurs primarily at the interface of syntax and pragmatics/semantics" (Bullock and Toribio 2004: 92). In addition, they claim that syntax proper (the purely formal system) is immune to 
convergence (but see Treffers-Daller and Mougeon 2005 and Backus, 2004 for counterarguments).

Silva-Corvalán (1994: 4) points to the fact that "transfer leads to, but is not the single cause of convergence, defined as the achievement of greater structural similarity in a given aspect of the grammar of two or more languages". She also mentions the importance of the fact that the languages are assumed to be different at the onset of contact, a point which is crucial, but not always easy to establish if historical data are not available. She discusses different types of transfer, described as DIRECT TRANSFER and INDIRECT TRANSFER. The former refers to the importation into a language of a new form from another language, such as lonche 'lunch' in Los Angeles Spanish. When registrarse incorporates the meaning 'to register in school' from English, this is also considered an example of direct transfer. Indirect transfer refers to a higher frequency of usage of a form that corresponds to a structure of the contact language (for example the more frequent use of progressives in Spanish by Puerto Rican Spanish-English bilinguals in comparison with monolinguals). These terms are similar to the ones used by Mougeon, Nadasdi and Rehner (2005) who apply the terms OVERT and COVERT TRANSFER for these phenomena. To Silva-Corvalán, the loss of a category that does not have a parallel in the contact language, is also a form of indirect transfer. An example is the loss of adjective gender marking in some Spanish varieties of Los Angeles, or in (4a) and (4b), the loss of case marking on the German preposition zu 'to'.

Importantly, Silva-Corvalán (1994: 5) points to the fact that "convergence may result as well from pre-existing internally motivated changes in one of the languages, most likely accelerated [original emphasis] by contact, rather than as a consequence of direct interlingual influence." Researchers have often failed to disentangle internal and external causes in their study of the emergence of particular innovations, and have jumped to conclusions about transfer in cases where the result is most likely due 
to MULTIPLE CAUSATION (Thomason and Kaufman 1988). There are however many researchers_-in particular historical linguists—who dismiss explanations based on external factors. As Farrar and Jones (2000) explain: Examining whether contact plays a role in change is [ ] seen as a last resort, and "if in doubt" we should "do without" and simply not take this final step (Farrar and Jones 2002, p. 4). Rather than resorting to a multiple causation explanation, perhaps the true challenge for researchers in contact linguistics is to find better methodologies for teasing apart the effects of transfer from those of internal change.

Despite the terminological confusion, the key differences between convergence and transfer appear to be as follows: first, convergence is not necessarily externally motivated, whereas transfer by definition must be. Second, transfer implies directionality (for instance, from language A to language B), while convergence does not. Third, convergence used in the sense of Mougeon and Beniak (1993), often involves simplification of structures or features, whereas transfer can lead to COMPLEXIFICATION, (i.e. an unmarked feature is replaced by a marked feature).

An issue that will need to be investigated in future is to what extent internal and external change use the same mechanisms. According to Croft (2000: 148) "essentially the same mechanism that causes interference also causes the innovation of certain types of internal language changes". Croft reserves the term INTRAFERENCE for processes of internal change such as morphological levelling whereby one form in a morphological paradigm spreads to other forms from that paradigm. A key aspect of this process is INTRALINGUAL IDENTIFICATION, i.e. "the recognition of the semantic relatedness of words, inflections and constructions" (Croft 2000: 148). Interference works in the same way, in his view, except that a form spreads from one language to another, rather than from one subsystem of a language to another subsystem of the same language, through a process of INTERLINGUAL IDENTIFICATION. This issue is 
important, as it raises the question to what extent contact-induced change is fundamentally different from internal mechanisms of language change (see also the conclusion of this chapter).

\subsection{Transfer in second language acquisition}

It is clear from all introductions to SLA that transfer is a key concept that needs to form part of any theory of SLA, despite the efforts of Dulay and Burt (1974) to minimize its role. Dechert and Raupach (1989: xii) consider language transfer to be a metaphorical concept, "because nothing is really 'transferred' from one domain to the other when we speak or listen to a new language". They distinguish no less than seventeen "shades of meaning" attributed to the term language transfer, and even this list is not intended to be complete. Depending on the aims of the study and the theoretical framework in which researchers work, transfer is seen, for example, as a research paradigm (Osgood 1953), a central process underlying language performance (Selinker 1972), a production strategy or a communication strategy (Gass and Selinker 1983), or a constraint on the hypotheses that learners will formulate about the target language (Schachter 1993). It is also clear that transfer can take place from L1 to L2 or from L2 to L1 (Pavlenko 2000; Cook 2003).

While researchers working from the perspective of Universal Grammar (UG) do not always think of transfer as key, White (2000) identifies five different approaches to this issue. The most extreme position taken in relation to transfer in SLA is expressed in what has become known as the Full Transfer/Full Access model (Schwartz and Sprouse 1996). Adherents of this model believe that learners initially transfer all the parameter settings from their first language into the L2. Subsequently they revise their hypotheses on the basis of positive evidence from the input (Mitchell and Myles 2004). If such evidence is not available or is obscure, learners do not become fully competent in the $L 2$, which explains fossilization. Others believe that learners have access to UG via their L1, or that only lexical 
categories are transferred, but not functional categories (Vainikka and Young-Scholten 1996a , 1996b).

Jarvis (2000) points out that there are so many conflicting findings about the importance of transfer in SLA, because researchers do not agree about the "nature" of transfer and they adopt different definitions of the concept. He proposes a working definition of L1 transfer: $L 1$ influence refers to any instance of learner data where a statistically significant correlation (or probability-based relation) is shown to exist between some features of learners' IL [interlanguage] performance and their L1 background (Jarvis (2000: 252)." This definition focuses on the empirical evidence that supports an explanation that transfer is the likely cause for a particular phenomenon.

\section{Conclusion: towards a unified account of code-switching and transfer}

In this Chapter we have seen that the wide variety of concepts used for contact phenomena makes it difficult for researchers to incorporate findings from neighboring fields into their research. The key question is of course whether researchers are only using different labels for essentially the same phenomena, or whether the phenomena under investigation are fundamentally different either in their surface manifestations, or in the processes and mechanisms that lead to those surface forms. The problem is often that surface forms as found in corpora of spontaneous bilingual speech can be the result of different processes that cannot be directly observed, whereas in strictly controlled experiments only a small proportion of the phenomena that can be observed "in the wild" can be tested (see also Gullberg and Muysken, this volume, who call for a multi-task approach to solve this problem).

A number of general points can however be made to advance the discussion. While many researchers have argued that CS and transfer are different phenomena altogether, new insights from psycholinguistics may well point into a different direction. As we have 
seen in section 1 Paradis (1998; in De Bot 2002: 291) argues that in terms of processing, cross-linguistic influence cannot be distinguished clearly from CS phenomena. The position that CS and transfer are manifestations of the same phenomenon, i.e. the influence of one language on another, is an attractive null hypothesis that can be tested in experimental settings. A key question to be investigated is in this context the issue of control: a further investigation of the locus and manner in which speakers control CS and transfer will no doubt shed new light on this matter.

Another key point that needs further investigation is to what extent the language selection processes that are involved in CS are the same or different from those that are used in lexical access in monolinguals. If Paradis (2004) is right, language processing in bilinguals and monolinguals works in the same way, so that no additional mechanisms are needed to account for CS. As we have seen above, Poulisse and Bongaerts (1994) provide evidence to support a unified approach to processing in monolinguals and bilinguals. While Paradis' position is an interesting null hypothesis, I have argued in this Chapter that we do need additional mechanisms, such as a mechanism for establishing congruence between languages. Independent support for the existence of such a mechanism comes from Croft (2000) who sees interlingual identification as a key mechanism behind contact-induced change.

It may be possible to go further and see intralingual processes such as analogical change in theories of language change or overgeneralization in L1 or L2 development as the counterpart of transfer among monolinguals. If speakers regularize irregular verbs (e.g. goed for went) this can also be seen as transfer of a pattern to a new domain. Similarly, it is possible to see accommodation (Giles and Powesland 1975) as a form of transfer of features between interlocutors. Transfer may thus well be a powerful mechanism that can be seen to work in monolingual and bilingual contexts. Whether or not the same processes are at work in these different contexts, and whether or not the notion language transfer is 
merely a metaphor (Dechert and Raupach 1989) or more than that, are empirical questions, surely worth investigating in the future. 
Bibliography

Abutalebi, J., Cappa, S.F., \& Perani, D. (2001). The bilingual brain as revealed by functional neuroimaging. Bilingualism: Language and Cognition, 4 (2), 179-190.

Auer, Peter. 1984. Bilingual Conversation. Amsterdam: John Benjamins.

Auer, Peter (1995) The pragmatics of code-switching: a sequential approach. In Lesley Milroy and Pieter Muysken (eds.) One speaker, two languages. Cross-disciplinary perspectives on code-switching, pp. 115-135.

Auer, Peter (1998) Code-switching in conversation. Language, interaction and identity. London and New York: Routledge.

Backus, Ad (2003) Units in codeswitching: evidence for multimorphemic elements in the lexicon. Linguistics, 41, 83-132

Bentahila, Abdelâli and Davies, Eileen D (1983) The syntax of Arabic-French codeswitching. Lingua 59: 301-30.

Boeschoten, H. (1998): Codeswitching, codemixing, and code alternation: What a difference. In: Jacobson, Rodolfo. (Hg.): Codeswitching worldwide. Berlin: Mouton de Gruyter, 15-24.

Bolle, Jette (1994) Sranan-Tongo Nederlands. Codewisseling en ontlening. MA thesis in Linguistics. University of Amsterdam. 
Bullock, B.E. \& Gerfen, C. (2004). Phonological convergence in a contracting language variety. Bilingualism: Language and Cognition, 7 (2), 95-104.

Bullock, B.E. \& Toribio, A.J. (eds.) (2004). Bilingualism and linguistic convergence. Special issue of Bilingualism: Language and Cognition, 7 (2).

Cenoz, Jasone \& Ulrike Jessner, eds (2000): English in Europe: The Acquisition of a Third Language, Multilingual Lingual Matters Ltd.

Chaudenson, R. \& Mougeon, R. \& Beniak, E. (1993). Vers une approche panlectale de la variation du français. Institut d'Etudes Créoles et Francophones. URA 1041 du CNRS, Université de Provence. Diffusion: Didier Erudition.

Clyne, M.G. (1987). Constraints on code switching: how universal are they? Linguistics, 25 (4), 739-764.

Clyne, M.G. (2003). Dynamics of language contact. English and immigrant languages. Cambridge: Cambridge University Press.

Cook, Vivian (ed.) (2003) Effects of the second language on the first. Clevedon, UK: Multilingual matters.

Coetsem, Frans van (1988) Loan phonology and the two transfer types in language contact. Dordrecht: Foris publications.

Costa, Albert, Wido La Heij and Eduardo Navarrete (2006). The dynamics of bilingual access. Bilingualism, Language and Cognition 9 (2), 137-151.

Croft, William (2000) Explaining language change: an evolutionary approach. Longman. 
Dawkins, R. M. (1916) Modern Greek in Asia Minor: a study of the dialects of Silli, Cappadocia and Phárasa with grammars, texts, translations, and glossary. Cambridge: Cambridge University Press

de Bot, Kees (1992) A bilingual production model: Levelt's 'speaking' model adapted. Applied Linguistics 13/1:1-24.

de Bot, Kees (2002) Cognitive Processing in Bilinguals: Language Choice and CodeSwitching. In: Robert B. Kaplan (ed.) (2002) The Oxford Handbook of Applied Linguistics, 287-300.

Dechert, Hans W. and Manfred Raupach (1989) Transfer in language production. Norwood, New Jersey: Ablex Publishing Corporation.

Deuchar, Margaret (2005) Congruence and Welsh-English code-switching. Bilingualism, Language and Cognition 8 (3), 255-269.

Dewaele, Jean-Marc (2003) Focus on French as a foreign language. Clevedon: Multilingual matters.

Dulay, H. and Burt, M (1974) Natural sequences in child second language acquisition. Language Learning, 24, 37-53. 
Dijkstra, Ton (2005) Bilingual word recognition and lexical access. In J.F. Kroll \& A.M.B. De Groot (eds.) Handbook of Bilingualism: Psycholinguistic Approaches, pp. 179-201. New York: Oxford University Press.

Dijkstra, Ton and Walter J. B. van heuven (1998) The BIA model and bilingual word recognition. In J. Grainger and A.M. Jacobs (eds.) Localist connectionist approaches to human cognition, p.p.189-225. Mahwah, NJ: Lawrence Erlbaum Associates

Dijkstra, Ton and Walter J.B. van Heuven (2002) The architecture of the bilingual word recognition system: From identification to decision. Bilingualism, Language and Cognition 5 (3), 175-197.

Farrar, K. \& Jones, M.C. (2002). Introduction. In M.C. Jones \& E. Esch (eds.), Language change, the interplay of internal external and extra-linguistic factors, pp. 1-16. Berlin/New York: Mouton de Gruyter.

Finkbeiner, Matthew, Tamar H. Gollan and Alfonso Caramazza (2006) Lexical access in bilingual speakers: What's the (hard) problem? Bilingualism, Language and Cognition 9 (2), 153-166.

Gass, Susan (1996) Second language acquisition and linguistic theory: the role of language transfer. In W. Ritchie and T.K. Bhatia (eds) Handbook of Second Language Acquisition. San Diego: Academic Press, 317-45.

Gass, Susan and Larry Selinker (1983) Language transfer in language learning. Rowley, M: Newsbury House. 
Giles, Howard. and Peter.F. Powesland (1975) A Social Psychological Model of Speech Diversity. In: Giles, H. and Powesland, P.F. (1975) Speech Style and Social Evaluation [European Monographs in Social Psychology]. New York: Harcourt Brace, pp. 154-70.

Green, David (1998) Mental control of the bilingual lexico-semantic system. Bilingualism: Language and Cognition 1, 67-81.

Grosjean, François. 1988. Exploring the recognition of guest words in bilingual speech. Language and CognitiveProcesses 3:233-274.

Grosjean, F. (1995) A psycholinguistic approach to code-switching: the recognition of guest words by bilinguals. in: Milroy, Lesley and Muysken, Pieter, (eds) One speaker, two languages. Cross-disciplinary perspectives on code-switching, 259-275.

Grosjean, F. (1998) Studying bilinguals: Methodological and conceptual issues. Bilingualism, Language and Cognition 1 (2), 131-149.

Grosjean, F. (2001). The bilingual's language modes. In Nicol, J. (Ed.). One mind, two languages: Bilingual language processing (pp. 1-22). Oxford: Blackwell

Haugen, Einar (1972a) The stigmata of bilingualism. In Anwar S. Dil (ed.) (1972) The ecology of language. Essays by Einar Haugen. Stanford, CA: Stanford University 
Hymes, Dell (1972) Models of the Interaction of Language and Social Life. In Gumperz and Hymes (eds.) (1972) Directions in Sociolinguistics. New York: Holt, Rinehart, Winston, p.35-71.

Haugen, Einar (1972b) The analysis of linguistic borrowing. Press, In Anwar S. Dil (ed.) (1972) The ecology of language. Essays by Einar Haugen. Stanford CA: Stanford University, pp. 308-25.

Heller, Monica (1988) Codeswitching. Anthropological and Sociolinguistic perspectives. Berlin etc. Mouton de Gruyter.

Hock, Hans H. (1991) Principles of historical linguistics; second, corrected and augmented edition. Berlin: Mouton de Gruyter.

Jarvis, Scott (2000) Methodological rigor in the study of transfer: Identifying L1 influence in the interlanguage lexicon. Language Learning 50, 245-309

Kellerman, E. \& Sharwood Smith, M. (eds.) (1986). Crosslinguistic influence in second language acquisition. New York etc.: Pergamon Institute of English. Kroll, Judith, Susan C. Bobb and Zofia Wodniecka (2006) Language selectivity is the exception, not the rule: Arguments against a fixed locus of language selection in bilingual speech. Bilingualism, Language and Cognition 9 (2), 119-135.

Lado, R. (1957). Linguistics across cultures. Ann Arbor: University of Michigan Press. 
La Heij, W. (2005) Selection processes in monolingual and bilingual lexical access. In J.F. Kroll \& A.M.B. De Groot (eds.) Handbook of Bilingualism: Psycholinguistic Approaches, pp. 287-307. New York: Oxford University Press.

Labov, William (1971) Some principles of linguistic methodology. Language in Society $1: 97-120$

Lefebvre, C. (1998). Creole genesis and the acquisition of grammar: The case of Haitian creole. Cambridge University Press, Cambridge

Levelt, Willem (1989) Speaking: from intention to articulation. Cambridge, MA: MIT Press.

Li Wei (1998) The 'why' and 'how' questions in the analysis of conversational codeswitching. In P. Auer (ed.) (1998) Code-Switching in Conversation. Language, interaction and identity. London/New York, 156-179

McClure, Erica (1977) Aspects of code switching among Mexican-American children. In Muriel Saville-Troike (ed.) Linguistics and Anthropology, Washington D.C.: Georgetown University Press, 93-115.

Meuter, Renata F.I. (2005) Language Selection in Bilinguals: Mechanisms and Processes. In J. Kroll and A.M.B. de Groot (eds.) Handbook of Bilingualism. Psycholinguistic Approaches, 349-370.

Mitchell, Rosamond and Florence Myles (2004) Second language learning theories (2nd edition). London: Arnold. 
Montrul, Silvina (2002). Incomplete acquisition and attrition of Spanish tense/aspect distinctions in adult bilinguals. Bilingualism, Language and Cognition 5 (1), 39-68 Moyer, Melissa (1998) "Bilingual conversation strategies in Gibraltar", in: Code-Switching in Conversation. Language, interaction and identity, Auer, Peter (1998), ed., London/New York, 215-234

Muysken, P. (2000). Bilingual Speech: A typology of code-mixing. Cambridge: Cambridge University Press Muysken, P.C. (2005). Modeling language contact (otra vez) Bilingual optimisation strategies. In Giorgio Banti, Antonietta Marra, \& Edoardo Vineis (Eds.), Atti del 40 congresso di studi dell'Associazone Italiana di Linguistica Applicata (pp. 11-36). Perugia: Guerra Edizioni.

Myers-Scotton, C. (1993a) Duelling Languages. Grammatical Structure in Codeswitching. Oxford: Clarendon Press.

Myers-Scotton, C. (1993b) Social Motivations for Codeswitching. Oxford: Clarendon Press Myers-Scotton (2002) Contact Linguistics. Bilingual encounters and grammatical outcomes. Oxford University Press.

Myers-Scotton, C. (2006) Natural codeswitching knocks on the laboratory door. Bilingualism, Language and Cognition, 9 (2), 203-212.

(Myers-)Scotton, C. and W. Ury (1977) Bilingual strategies: the social function of codeswitching. International Journal of the Sociology of Language 13, 5-20. 
Nortier, Jacomien (1990) Dutch-Moroccan Arabic code-switching among young Moroccans in the Netherlands, Dordrecht.

Odlin, Terrence (2003) Cross-linguistic influence. In: Catherine J. Doughty and Michael H.Long (eds.) (2003) The Handbook of Second Language Acquisition, 436-486.

Osgood, C.E. (1953) Method and theory in experimental psychology. New York: Oxford University Press.

Paradis, Michel (1981) Neurolinguistic organization of a bilingual's two languages. In J. E. Copeland and P. W. Davis (eds.) The Seventh Lacus Forum. Columbia, SC: Hornbeam Press, 486-494.

Paradis, Michel (1987) Neurolinguistic perspectives on bilingualism. In M. Paradis \& G. Libben (eds) The assessment of bilingual aphasia. Hillsdale, NJ; Lawrence Erlbaum, 117.

Paradis, Michel (1993) Linguistic, psycholinguistic and neurolinguistic aspects of "interference" in bilingual speakers: the Activation Threshold Hypothesis. International Journal of Psycholinguistics 9, 133-145.

Paradis, Michel (1998) Aphasia in bilinguals: How atypical is it? In P. Coppens, Y. Lebrun, and A. Basso (eds.) Aphasia in atypical populations. Mahwah, NJ: Lawrence Erlbaum, 35-66. 
Paradis, Michel (2004) A neurolinguistic theory of bilingualism. Amsterdam/Philadelphia: John Benjamins.

Pavlenko, Aneta (2000) L2 influence on L1 in late bilingualism. Issues in Applied Linguistics, 11, 175-205.

Pfaff, Carol (1979) "Constraints on language mixing: intrasentential code-switching and borrowing in Spanish/English", in: Language 55 (2), 291-318.

Pienemann, Manfred (1999) Language Processing and Second Language Development. Processability Theory. Amsterdam: John Benjamins.

Polinsky, Maria (2004). Word class distinctions in an incomplete grammar. In Dorit Ravid and Hava Bat-Zeev Shyldkrot, eds. Perspectives on language and language development. Dordrecht: Kluwer

Poplack, Shana (1980) "Sometimes I'll start a sentence in Spanish y termino en español: Toward a typology of code-switching", in: Linguistics 18, 581-618.

Poplack, Shana (1987) Contrasting patterns of code-switching in two communities. In Erling Wande, Jan Anward, Bengt Nordberg, Lars Steensland and Mats Thelander (eds.) Aspects of multilingualism. Proceedings from the Fourth Nordic Symposium on Bilingualism, 1984, pp. 51-77. 
Poplack, Shana (1990) "Variation theory and language contact: concepts, methods and data", in: Papers for the workshop on concepts, methodology and data, ESF Network on Code Switching and Language Contact. Basel, 33-65.

Poplack, Shana, Marjorie Meechan (1995) "Patterns of language mixture: nominal structure in Wolof-French and Fongbe-French bilingual discourse", in: One speaker, two languages. Cross-disciplinary perspectives on code-switching, Milroy, Lesley/Muysken, Pieter, eds., 199-232.

Poulisse, Nanda and Theo Bongaerts (1994) First Language Use in Second Language Production. Applied Linguistics 15 (1), 36-57.

Salmons, Joe (1990) Bilingual discourse marking: code switching, borrowing and convergence in some German-American dialects. Linguistics 28, 453-480.

Schachter, Jaquelyn (1993) A new account of language transfer. In S. Gass and L. Selinker (eds.) Language Transfer in Language Learning. Amsterdam: John Benjamins, $32-46$.

Schmidt, Johannes (1872) Die Verwandtschaftsverhältnisse der indogermanischen Sprachen. Weimar, H. Böhlau

Schwartz, Bonnie D. and Richard A. Sprouse (1996) L2 cognitive states and the full transfer, full access model. Second Language Research 12, 40-72. 
Sebba, Mark (1998) "A congruence approach to the syntax of codeswitching", in: International Journal of Bilingualism 2 (1), 1-20

Selinker, Larry (1972) Interlanguage. International Review of Applied Linguistics 10 (3), 209-231.

Silva-Corvalán, Carmen (1994) Language contact and change: Spanish in Los Angelos, Oxford.

Sorace, Antonella (2003) Near-Nativeness. In: Catherine J. Doughty and Michael H.Long (eds.) (2003) The Handbook of Second Language Acquisition, 130-151.

Stolt, Birgit (1964) Die Sprachmischung in Luther's 'Tischreden'. Stockholm: Almqvist and Wiksell.

Swigart, Leigh (1992) Two codes or one? The insiders view and the description of codeswitching in Dakar. Journal of Multilingual and Multicultural Development, vol 13: 1\&2, 83-102.

Thomason, S.G. \& Kaufman, T. (1988). Language contact, creolization and genetic linguistics. Berkeley/Los Angelos/London.

Treffers-Daller, J. (1999). Borrowing and shift-induced interference: Contrasting patterns in French-Germanic contact in Brussels and Strasbourg. Bilingualism: Language and Cognition, 2 (1), 1-22.

Treffers-Daller, Jeanine (1994) Mixing two languages: French-Dutch contact in a comparative perspective, Berlin: mouton de Gruyter 
Treffers-Daller, Jeanine (2005a) Evidence for insertional code-mixing: mixed compounds and French nominal groups in Brussels Dutch. In Backus, A.\& J.Nortier \& J.Treffers-Daller (eds). special issue of the International Journal of Bilingualism, vol. 9 (3\&4), pp. 477-508. ISSN 1367-0069

Treffers-Daller, Jeanine (2005b) Brussels French une fois: Transfer-induced innovation or system-internal development? Special issue of Bilingualism, Language and Cognition, vol 8 (2), pp. 145-157.

Treffers-Daller, J. and Mougeon, R. (2005) (eds.) The role of transfer in language variation and change: Evidence from contact varieties of French, Introduction to special issue of Bilingualism, Language and Cognition 8 (2), 93-98.

Treffers-Daller, J., Sumru Özsoy and Roeland van Hout (in press) (In)complete acquisition of Turkish among Turkish-German bilinguals in Germany and Turkey: an analysis of complex embeddings in narratives. To appear in: International Journal of Bilingualism and Bilingual Education (2007).

Trubetzkoy, N. 1939/69. Principles of phonology. Berkeley: University of California Press (1969). Translation by C. Baltaxe of Grundzüge der Phonologie. Göttingen: Vandenhoek and Ruprecht (1939).

Vainikka, A and Young-Scholten, M (1996a) The early stages in adult L2 syntax: additional evidence from Romance speakers. Second language research 12, 140-76. 
Vainikka, A and Young-Scholten, M (1996b) Gradual development of L2 phrase structure. Second Language Research 12, 7-39.

Valdés Fallis, Guadalupe 1976, "Social interaction and code-switching patterns : A case study of Spanish-English alternation" in KELLER G., TESCHENER R. \& VIERA S. (Eds.) Bilingualism in the bicentennial and beyond. New York: Bilingual Press, pp. 53-85.

Weinreich, Uriel (1953) Languages in Contact: Problems and Findings, New York

Weinreich, Uriel (1959) Is a structural dialectology possible? Word 10, 388-400.

White, Lydia (2000) Second language acquisition: from initial to final state. In J.Archibald (ed.) Second Language Acquisition and Linguistic Theory. Oxford: Blackwell, 130-155.

Winford, D. (2003). An introduction to contact linguistics. Oxford: Blackwell 